\title{
Article
}

\section{Modular sustainability within the landscape}

Derbyshire, Alan

Available at https://clok.uclan.ac.uk/5168/

Derbyshire, Alan (2009) Modular sustainability within the landscape. Design Principles and Practices: An International Journal, 3 (2). pp. 227-248. ISSN 1833-1874

It is advisable to refer to the publisher's version if you intend to cite from the work.

For more information about UCLan's research in this area go to

http://www.uclan.ac.uk/researchgroups/ and search for <name of research Group>.

For information about Research generally at UCLan please go to

http://www.uclan.ac.uk/research/

All outputs in CLoK are protected by Intellectual Property Rights law, including Copyright law. Copyright, IPR and Moral Rights for the works on this site are retained by the individual authors and/or other copyright owners. Terms and conditions for use of this material are defined in the policies page.

\section{CLoK}

Central Lancashire online Knowledge www.clok.uclan.ac.uk

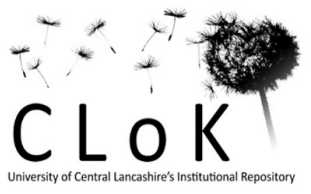


This study examines the ecological and creative potential of sustainable traditional and contemporary hard landscaping materials within the corporate, civic and domestic environment. It focuses on the commonalities and shared design issues which link the architect, landscape architect and the enthusiastic amateur, and how their collective response to sustainability are fundamentally interdependent. Satellite and aerial imagery of the earth reveal patterns of humanity in the form of structural fingerprints on the earth's surface. This is an unambiguous identifiable visual reference of our influence on the topography of our planet. Materials, man made and natural, are intrinsic to the process of designing and planning urban landscapes and environments. Embodied energy and remanufactured materials are as significant to the design brief as aesthetic and commercial considerations. Car parks for example are features that connect to the public in more ways than just the obvious. The effect of carpeting of the landscape with asphalt and the direct association with drainage and flooding have an impact on developments ranging from commercial complexes to domestic driveways. These common motifs are applicable to architects, designers and planners, in short, most constituents of property owning societies. The option of turning green to grey on the global blueprint is no longer credible. This paper considers how materials and ecology are implemented and evaluates the interpretation of the concept of sustainability influence the viability of successful outcomes. 